Article

\title{
Association between Heavy Metal Exposure and Dyslipidemia among Korean Adults: From the Korean National Environmental Health Survey, 2015-2017
}

\author{
Do-won Kim ${ }^{1,2,+}$, Jeongwon Ock ${ }^{1,+}$, Kyong-Whan Moon ${ }^{2, *(D)}$ and Choong-Hee Park $1, *$ (D) \\ 1 Environmental Health Research Division, National Institute of Environmental Research, Ministry of \\ Environment, Incheon 22689, Korea; done35005@gmail.com (D.-w.K.); ockjeongwon@korea.kr (J.O.) \\ 2 BK21 FOUR R \& E Center for Learning Health System, Department of Health and Environmental Science, \\ Korea University, Seoul 02841, Korea \\ * Correspondence: kwmoon@korea.ac.kr (K.-W.M.); whoispch@korea.kr (C.-H.P.); \\ Tel.: +82-02-3290-5692 (K.-W.M.); +82-32-560-7126 (C.-H.P.); Fax: +82-32-568-2035 (C.-H.P.) \\ + These authors contributed equally to this work.
}

check for updates

Citation: Kim, D.-w.; Ock, J.; Moon, K.-W.; Park, C.-H. Association between Heavy Metal Exposure and Dyslipidemia among Korean Adults: From the Korean National Environmental Health Survey, 2015-2017. Int. J. Environ. Res. Public Health 2022, 19, 3181. https:// doi.org/10.3390/ijerph19063181

Academic Editors: Roberto Alonso González Lezcano, Francesco Nocera and Rosa Giuseppina Caponetto

Received: 24 January 2022

Accepted: 3 March 2022

Published: 8 March 2022

Publisher's Note: MDPI stays neutral with regard to jurisdictional claims in published maps and institutional affiliations.

Copyright: (C) 2022 by the authors. Licensee MDPI, Basel, Switzerland. This article is an open access article distributed under the terms and conditions of the Creative Commons Attribution (CC BY) license (https:// creativecommons.org/licenses/by/ $4.0 /)$.

\begin{abstract}
Cardiovascular disease (CVD) is a leading cause of death in Korea. Dyslipidemia, characterized by the presence of abnormal lipid levels, has been suggested as an early diagnostic and preventable factor for CVD. Recent studies have shown that exposure to lead $(\mathrm{Pb})$, cadmium $(\mathrm{Cd})$, and mercury $(\mathrm{Hg})$ affects lipid metabolism. This study aimed to verify the association between heavy metal concentrations and serum lipid profiles in the general population. A representative sample of 2591 Korean adults from the Korean National Environmental Health Survey (2015-2017) was analyzed. The associations between heavy metals [Blood $\mathrm{Pb}(\mathrm{BPb})$, blood $\mathrm{Hg}(\mathrm{BHg})$, urinary $\mathrm{Hg}(\mathrm{UHg})$, urinary Cd (UCd)] and serum lipid profiles [total cholesterol (TC), triglyceride (TG), low-density lipoprotein cholesterol (LDL-C), non-low level of high-density lipoprotein cholesterol (Non-HDL-C)] were assessed using regression analysis. After adjusting for demographic and socioeconomic factors, the proportional changes in serum lipid levels were significantly associated with increases in $\mathrm{BPb}$, $\mathrm{BHg}$, and $\mathrm{UHg}$ levels ( $p$ for trend $<0.05$ ). Overall, $\mathrm{BPb}, \mathrm{BHg}$, and Uhg levels positively correlated with dyslipidemia, whereas UCd levels did not show a significant association. Our results suggest that heavy metal exposure, at low levels, may contribute to an increased prevalence of dyslipidemia in Korean adults.
\end{abstract}

Keywords: heavy metals; serum lipid profiles; dyslipidemia; KoNEHS

\section{Introduction}

Hypertension, hyperglycemia, and dyslipidemia are observed in individuals with metabolic syndrome [1]. Dyslipidemia is an important risk factor of cardiovascular disease (CVD) which is one of the diseases with high mortality worldwide [2]. In particular, dyslipidemia causes lipid accumulation in the arterial wall, which reduces blood flow to the heart, leading to CVD [3-5]. The prevalence of dyslipidemia is $53 \%$ and $45 \%$ in the United States and Canada [2,6] respectively. In Korea, the prevalence has increased from 34.1\% in 2010-2013 to 36.5\% in 2013-2015 [7,8]. Dyslipidemia is characterized by an imbalance of lipid levels in the blood, and it is caused by excessive entry of lipoproteins into the bloodstream or impaired ability to remove them [9-11].

Dyslipidemia is generally defined as elevated total cholesterol (TC), triglyceride (TG), low-density lipoprotein cholesterol (LDL-C), and a low level of non-high-density lipoprotein cholesterol (Non-HDL-C) [12-14]. Lifestyle features, such as dietary habits, lack of exercise, and alcohol consumption are commonly known risk factors for dyslipidemia [15]; however, several recent epidemiological studies suggest that abnormal lipid metabolism is associated with environmental chemical exposure [16-19]. Heavy metals, such as lead 
$(\mathrm{Pb})$, cadmium $(\mathrm{Cd})$, and mercury $(\mathrm{Hg})$, are released into the environment by natural and anthropogenic sources [20,21]. Human anthropogenic activities (e.g., agricultural, household, and industrial activities) have increased exposure to heavy metals through respiratory and dietary intake [22]. Environmental exposure to heavy metals occurs through breathing contaminated air, eating plants, and drinking water from contaminated soil or groundwater [23].

Heavy metals can accumulate in various tissues and exhibit toxic effects on intracellular metabolic processes (DNA damage, oxidative proteolysis, etc.) [24]. As a result, heavy metal exposure can cause various diseases [25]. Oxidative stress is one of the most important consequences of heavy metal exposure [26]. In particular, the production of hydroxyl $(\bullet \mathrm{OH})$ and peroxynitrite (ONOO-), which are involved in oxidative stress, are known to cause lipid imbalance and CVD $[27,28]$. In conclusion, heavy metal exposure may affect an increase in cholesterol, triglyceride, and lipoprotein content [28]. According to previous studies, $\mathrm{Xu}$ et al. (2021) reported significant increases in TC, Non-HDL-C, and LDL-C levels with $\mathrm{Pb}$ exposure in the US adult population [29]. A significant association has been proposed between Cd-exposed Korean adults and an increased risk of dyslipidemia [30]. Participants with above-average $\mathrm{Hg}$ concentrations were reported to have a higher risk of dyslipidemia than those who did not [31]. However, heavy metal toxicity depends on several factors, including the age, gender, genetics, and nutritional status of the exposed individual [32]. As heavy metal concentrations in Korean are higher than those in developed countries [33], low levels of chronic heavy metal exposure remain a public health concern. In addition, only a few studies have been conducted to investigate the association between heavy metal exposure and dyslipidemia in Koreans. Therefore, it is necessary to confirm the effect of heavy metals on the serum lipid profile of a representative adult sample of Korea. In the present study, we investigated blood and urine heavy metals $(\mathrm{Pb}, \mathrm{Cd}, \mathrm{Hg})$, as well as serum lipid profiles (0, TG, LDL-C, non-HDL-C) provided in the Korea National Environmental Health Survey (KoNEHS) 2015-2017.

\section{Methods}

\subsection{Study Population}

The KoNEHS is a cross-sectional survey conducted every 3 years since 2009. The survey was designed to estimate and monitor exposure to various environmental pollutants in a representative Korean adult population. We analyzed the association between heavy metal exposure and serum lipid profile using data from 2015 to 2017, provided by KoNEHS. The national survey consists of a questionnaire, a physical examination, and the collection and analysis of biological samples, including a total of 26 chemicals and 16 clinical trial samples. Through a survey of trained investigators, six categories of information were obtained, including demographic and socioeconomic questions. Biological samples were collected by medical technicians and nurses under the supervision of a physician. In KoNEHS cycle 3, urine and blood samples were collected from a total of 3787 adults, aged 19 years and older. The following participants were excluded from the study (Figure 1): those who self-reported taking medications for hypertension or hyperlipidemia $(n=997)$, those who were not tested for heavy metals or serum lipid profiles $(n=34)$, and those with TG levels above $400 \mathrm{mg} / \mathrm{dL}(n=151)$, according to the Friedewald's equation, used to calculate LDL-C levels. Participants without urine creatinine concentration information, as well as demographic and socio-economic information used as covariates $(n=14)$, were also excluded. Therefore, a total of 2591 participants were used for the analysis. This study was approved by the Research Ethics Committee of the National institute of Environmental Research [34]. 


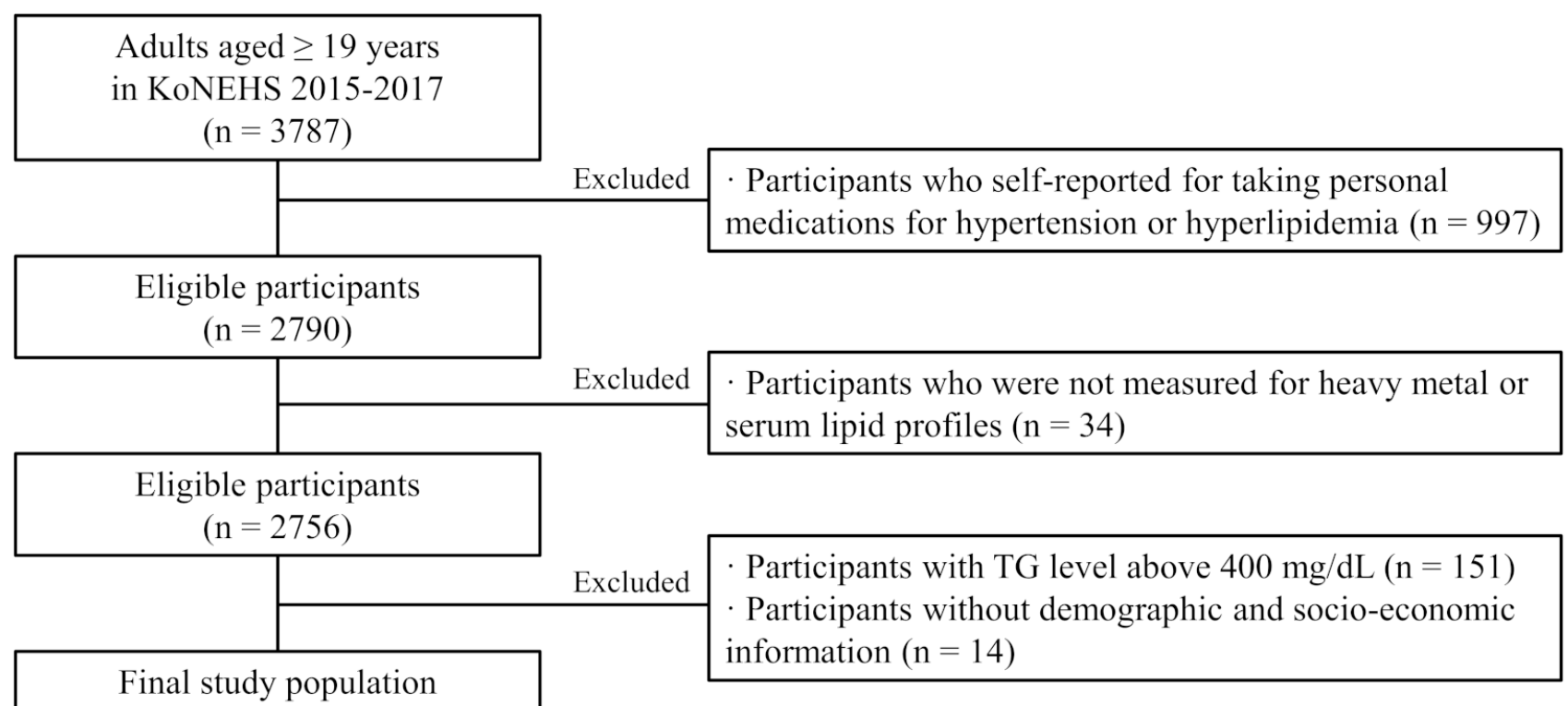

Figure 1. Participant flow chart of Korea National Environmental Health Survey (KoNEHS) 2015-2017 data available in this study.

\subsection{Measurement of Heavy Metals}

KoNEHS analyzed three heavy metals, including $\mathrm{Pb}, \mathrm{Cd}$, and $\mathrm{Hg}$. Among these, $\mathrm{Pb}$ and total $\mathrm{Hg}$ were analyzed in blood, while $\mathrm{Hg}$ and $\mathrm{Cd}$ were analyzed in spot urine. Blood samples and spot urine samples were collected using a blood collection vessel (VACCUTAINER Royal blue cap) and a sterile urine collection vessel (sample cup), respectively. The samples were maintained at $2-6{ }^{\circ} \mathrm{C}$, using an ice box, and refrigerated at $-20{ }^{\circ} \mathrm{C}$ for future analysis. Blood $\mathrm{Pb}(\mathrm{BPb})$ and urine $\mathrm{Cd}(\mathrm{UCd})$ were analyzed using graphite furnaceatomic absorption spectroscopy (AAnalyst-800, Perkin Elmer) at wavelengths of 283.3 and $228.8 \mathrm{~nm}$, respectively. Mercury concentrations in blood $(\mathrm{BHg})$ and urine $(\mathrm{UHg})$ were analyzed at wavelengths of 254.65 and $253.7 \mathrm{~nm}$, respectively, using a gold amalgamation direct mercury analyzer (DMA-80, Milestone). The limits of detection (LOD) of heavy metals $(\mathrm{Pb}, \mathrm{Cd}$, and $\mathrm{Hg}$ ) were $0.3 \mu \mathrm{g} / \mathrm{dL}, 0.1 \mu \mathrm{g} / \mathrm{L}$, and $0.05 \mu \mathrm{g} / \mathrm{L}$, respectively [35]. Values below the LOD of $\mathrm{Pb}, \mathrm{Cd}$, and $\mathrm{Hg}$ were substituted with the square root of the LOD. The quality control procedure was conducted using the standardized protocol procedure of the National Academy of Environmental Sciences.

\subsection{Measurement of Serum Lipid Profile}

KoNEHS collected total cholesterol (TC), Triglyceride (TG), and high-density lipoprotein cholesterol (HDL) from serum samples. Whole blood samples were collected in serum separation tubes (SST). The samples were mixed by inversion, held for $30 \mathrm{~min}$, and then, centrifuged at 3500 RPM (revolutions per minute). TC, TG, and HDL-C levels were analyzed using an automated analyzer (ADVIA 1800; Siemens Medical Solutions, Ann Arbor, MI, USA) at 505/694, 505/694, and $596 \mathrm{~nm}$ wavelengths, respectively. The limits of detection (LOD) for TC, HDL-C, and TG were 10.0, 5.0, $10.0 \mathrm{mg} / \mathrm{dL}$, respectively [36]. Values below the LOD of TC, HDL-C, and TG were replaced with the square root of the LOD.

\subsection{Evaluation of Serum Lipid Profile}

Dyslipidemia was defined as the presence of one or more of the following: TC $\geq$ $200 \mathrm{mg} / \mathrm{dL}, \mathrm{TG} \geq 150 \mathrm{mg} / \mathrm{dL}, \mathrm{LDL}-\mathrm{C} \geq 130 \mathrm{mg} / \mathrm{dL}$, and non-HDL-C $\geq 160 \mathrm{mg} / \mathrm{dL}[12,37]$. In this study, LDL-C and non-HDL-C levels were obtained using indirect methods. LDL$\mathrm{C}$ was calculated as TC-HDL(C)-[TG/5] using Friedewald's formula [38]. Owing to a limitation of the formula, TG values greater than $400 \mathrm{mg} / \mathrm{dL}$ were treated as missing 
values [39,40]. This is because TG levels above $400 \mathrm{mg} / \mathrm{dL}$ may be underestimated, owing to a decrease in the TC:TG ratio of very low-density lipoprotein cholesterol (VLDL-C) [38]. Non-HDL-C was calculated as TC - HDL(C) [41]. Indirectly estimated non-HDL-C levels may be a better indicator of atherosclerotic lipoprotein particles than HDL-C levels [42,43]. KoNEHS samples could be used since fasting conditions are not required for lipid analysis.

\subsection{Covariates}

Covariates were chosen based on the associations between serum lipid profiles, according to the following characteristics provided in previous epidemiological studies [22,44]: age (19-39, 40-59, and 60 years or older); sex (Male, female); body mass index (BMI) calculated by dividing body weight $(\mathrm{kg})$ by the square of height, and then, divided into categories of underweight (<18.5), normal (18.5-23), overweight (23-25), and obese (>25), according to the criteria of the Korean Society for the Study of Obesity (KOSSO); household income [low < 840; medium, 840-4220; high $\geq 4220$ US dollars]; education ( $\leq$ middle school; high school; $\geq$ college); smoking status (non-smoker, former smoker, current smoker); alcohol consumption [non-drinkers, light drinkers (twice a month), heavy drinker (once a week to almost daily)]; physical activity (none, moderate, and rarely).

\subsection{Statistical Analysis}

Stratum and cluster weights were applied to the regression model to consider a twostep proportional stratified sample design for KoNEHS data. For the analysis, differential probabilities of selection, non-response, and sample weights were applied. Serum lipid profiles were normally distributed and calculated as the arithmetic mean. The heavy metal concentrations did not follow a normal distribution, and the geometric means was calculated by log-transformation. Student's $t$-test and analysis of variance (ANOVA) were used to analyze statistical differences between different groups for continuous variables. Heavy metal concentrations were divided into quartiles, and serum lipid profiles were used as continuous variables. The mean change in serum lipid profile concentration by heavy metal concentration was analyzed using multiple linear regression analysis. For multivariate logistic regression, serum lipid profiles were divided into two groups, based on cholesterol levels (dyslipidemia or non-dyslipidemia by cholesterol levels) and the odds ratio [OR, 95\% confidence interval (CI)] of dyslipidemia by heavy metal concentration. A value of $p<0.05$ was considered as statistically significant in all analyses. Statistical analysis was performed using the Statistical Analysis System (SAS) 9.4 software.

\subsection{Sensitivity Analysis}

First, as a limitation of the use of the LDL-C estimation formula, exclusion of participants with TG $\geq 400$, may have confounded the results of other serum lipid profiles. Therefore, we performed an additional sensitivity analysis, for OR, of serum lipid profiles (TC, TG, and non-HDL-C) by heavy metal concentration in 2742 participants, including $\mathrm{TG} \geq 400$. Second, after further adjustment for heavy metal-related occupations for high exposure, the association between heavy metal exposure and serum lipid profile was analyzed. This analysis was performed on 74 participants involved in occupations related to heavy metals among 2951 participants with occupational data. Third, since non-occupational $\mathrm{Hg}$ exposure is primarily due to seafood consumption, we further adjusted for the high seafood dietary group. The high seafood consumption group was calculated by the sum of the frequency of consuming one or more of the five items (large fish and tuna, crustaceans, shellfish, and other seafood) at least once a week. Therefore, 1627 participants were classified into the high seafood dietary group, and the remaining 964 participants constituted the other group. 


\section{Results}

Demographic Characteristics and Serum Lipid Profiles

The weighted arithmetic means (AM) of TC, TG, LDL-C, and non-HDL-C were $185.70(0.97), 145.42$ (2.17), $99.10(0.87)$, and $128.18(0.97) \mathrm{mg} / \mathrm{dL}$, respectively (Table 1$)$. Serum lipid profile levels were significantly higher in male than in female, and they significantly increased with age and BMI $(p<0.001)$. In participants with low household income, TG significantly increased $(p<0.05)$. Participants with low education levels had higher serum lipid profile levels $(p<0.05)$. Participants who smoked had significantly higher lipid levels than those who did not $(p<0.05)$. TG was significantly linked with drinking status $(p<0.05)$. In terms of physical activity, only TG was significantly lower in the group, with hardly any physical activity compared with the reference group $(p<0.05)$.

Table 1. Arithmetic means $(\mathrm{mg} / \mathrm{dL})$ of serum lipid profiles $(\mathrm{mg} / \mathrm{dL})$ in participants $(n=2591)$ by demographic characteristics.

\begin{tabular}{|c|c|c|c|c|c|c|c|c|c|c|}
\hline \multirow[b]{2}{*}{ Total } & \multicolumn{2}{|c|}{$\begin{array}{c}n \\
(\%)\end{array}$} & \multicolumn{2}{|c|}{$\begin{array}{c}\text { TC } \\
(\mathrm{mg} / \mathrm{dL}(\mathrm{SE}))\end{array}$} & \multicolumn{2}{|c|}{$\begin{array}{c}\text { TG } \\
(\mathrm{mg} / \mathrm{dL}(\mathrm{SE}))\end{array}$} & \multicolumn{2}{|c|}{$\begin{array}{c}\text { LDL-C } \\
\text { (mg/dL (SE)) }\end{array}$} & \multicolumn{2}{|c|}{$\begin{array}{l}\text { Non-HDL-C } \\
\text { (mg/dL (SE)) }\end{array}$} \\
\hline & 2591 & $(100)$ & 185.70 & $(0.97)$ & 145.42 & $(2.17)$ & 99.10 & $(0.87)$ & 185.70 & $(0.97)$ \\
\hline Male & 1111 & $(49.4)$ & 182.52 & $(1.67)$ & 145.45 & $(3.08)$ & 95.00 & $(1.51)$ & 128.48 & $(1.63)$ \\
\hline Female & 1480 & $(50.6)$ & 182.58 & (1.11) & 110.71 & (1.98) & 93.86 & $(0.97)$ & 119.03 & (1.12) \\
\hline$p$-value & & & \multicolumn{2}{|c|}{$<0.001$} & \multicolumn{2}{|c|}{$<0.001$} & \multicolumn{2}{|c|}{0.249} & \multicolumn{2}{|c|}{$<0.001$} \\
\hline \multicolumn{11}{|l|}{ Age group (years) } \\
\hline $19-39$ & 766 & $(29.56)$ & 175.58 & $(1.54)$ & 116.95 & $(3.11)$ & 88.32 & $(1.41)$ & 115.55 & $(1.51)$ \\
\hline $40-59$ & 1152 & $(44.46)$ & 190.12 & $(1.20)$ & 134.35 & $(2.34)$ & 100.57 & $(0.99)$ & 131.07 & (1.14) \\
\hline$\geq 60$ & 673 & $(25.97)$ & 183.13 & (2.06) & 137.16 & (3.53) & 96.81 & (1.83) & 128.63 & $(2.07)$ \\
\hline$p$-value & & & \multicolumn{2}{|c|}{$<0.001$} & \multicolumn{2}{|c|}{$<0.001$} & \multicolumn{2}{|c|}{$<0.001$} & \multicolumn{2}{|c|}{$<0.001$} \\
\hline \multicolumn{11}{|l|}{ BMI $\left(\mathrm{kg} / \mathrm{m}^{2}\right)$} \\
\hline$<18.5$ & 82 & $(3.92)$ & 174.05 & $(5.25)$ & 95.39 & $(6.33)$ & 89.15 & $(3.62)$ & 108.23 & $(4.01)$ \\
\hline $18.5-22.9$ & 944 & $(39.0)$ & 177.41 & (1.33) & 115.01 & $(2.82)$ & 91.84 & $(1.11)$ & 114.84 & $(1.25)$ \\
\hline $23.0-25.0$ & 677 & $(25.9)$ & 191.55 & $(1.95)$ & 154.45 & $(3.47)$ & 104.59 & $(1.92)$ & 135.48 & $(2.03)$ \\
\hline$>25$ & 888 & (31.8) & 192.36 & (1.75) & 180.91 & $(4.00)$ & 104.61 & $(1.56)$ & 140.80 & $(1.64)$ \\
\hline$p$-value & & & \multicolumn{2}{|c|}{$<0.001$} & \multicolumn{2}{|c|}{$<0.001$} & \multicolumn{2}{|c|}{$<0.001$} & \multicolumn{2}{|c|}{$<0.001$} \\
\hline \multicolumn{11}{|c|}{ Household income (US\$/month) } \\
\hline $\begin{array}{l}\text { Low } \\
(840)\end{array}$ & 332 & $(12.81)$ & 180.64 & $(3.08)$ & 139.78 & $(5.73)$ & 94.08 & $(2.75)$ & 126.74 & $(2.97)$ \\
\hline Middle (840-4220) & 1777 & $(68.58)$ & 181.64 & $(1.09)$ & 124.58 & $(2.23)$ & 94.05 & $(1.01)$ & 122.59 & $(1.08)$ \\
\hline $\begin{array}{c}\text { High } \\
(\geq 4220)\end{array}$ & 482 & $(18.60)$ & 185.86 & $(2.02)$ & 129.04 & $(4.42)$ & 95.64 & $(1.78)$ & 125.65 & (1.98) \\
\hline$p$-value & & & \multicolumn{2}{|c|}{0.063} & \multicolumn{2}{|c|}{0.006} & \multicolumn{2}{|c|}{0.729} & \multicolumn{2}{|c|}{0.103} \\
\hline \multicolumn{11}{|l|}{ Education levels } \\
\hline$\leq$ Middle school & 641 & $(24.74)$ & 187.29 & $(1.69)$ & 135.53 & $(2.99)$ & 99.84 & $(1.60)$ & 131.36 & $(1.60)$ \\
\hline $\begin{array}{l}\text { High } \\
\text { school }\end{array}$ & 847 & (32.69) & 184.23 & $(1.47)$ & 130.27 & (3.16) & 96.52 & (1.19) & 126.35 & (1.40) \\
\hline$\geq$ College & 1103 & $(42.57)$ & 180.52 & $(1.37)$ & 122.76 & $(2.66)$ & 92.05 & $(1.31)$ & 120.35 & $(1.32)$ \\
\hline$p$-value & & & \multicolumn{2}{|c|}{0.001} & \multicolumn{2}{|c|}{0.025} & & & & \\
\hline Smoking status & & & & & & & & & & \\
\hline Never & 1694 & $(65.38)$ & 181.05 & $(1.05)$ & 116.05 & $(2.03)$ & 93.44 & $(0.92)$ & 120.01 & (1.06) \\
\hline Former & 455 & $(17.56)$ & 187.55 & $(2.11)$ & 149.54 & $(4.36)$ & 99.08 & $(1.81)$ & 133.42 & (1.93) \\
\hline Current & 442 & $(17.06)$ & 183.27 & (2.15) & 145.87 & $(5.08)$ & 93.81 & (1.88) & 127.41 & $(2.21)$ \\
\hline$p$-value & & & & & & & & & & \\
\hline
\end{tabular}


Table 1. Cont.

\begin{tabular}{|c|c|c|c|c|c|c|c|c|c|c|}
\hline \multirow{2}{*}{ Drinking status } & \multicolumn{2}{|c|}{$\begin{array}{c}n \\
(\%)\end{array}$} & \multicolumn{2}{|c|}{$\begin{array}{c}\text { TC } \\
(\mathrm{mg} / \mathrm{dL}(\mathrm{SE}))\end{array}$} & \multicolumn{2}{|c|}{$\begin{array}{c}\text { TG } \\
(\mathrm{mg} / \mathrm{dL}(\mathrm{SE}))\end{array}$} & \multicolumn{2}{|c|}{$\begin{array}{c}\text { LDL-C } \\
\text { (mg/dL (SE)) }\end{array}$} & \multicolumn{2}{|c|}{$\begin{array}{l}\text { Non-HDL-C } \\
(\mathrm{mg} / \mathrm{dL}(\mathrm{SE}))\end{array}$} \\
\hline & & & & & & & & & & \\
\hline Never & 783 & $(30.22)$ & 182.08 & $(1.57)$ & 123.99 & $(4.23)$ & 95.32 & $(1.44)$ & 123.86 & $(1.69)$ \\
\hline Light & 889 & $(34.31)$ & 180.61 & (1.78) & 118.92 & $(3.07)$ & 95.37 & (1.48) & 122.64 & (1.77) \\
\hline Heavy & 919 & $(35.47)$ & 184.57 & $(1.42)$ & 135.69 & $(3.51)$ & 93.06 & $(1.40)$ & 124.31 & $(1.40)$ \\
\hline$p$-value & & & \multicolumn{2}{|c|}{0.118} & \multicolumn{2}{|c|}{$<0.001$} & \multicolumn{2}{|c|}{0.099} & \multicolumn{2}{|c|}{0.760} \\
\hline \multicolumn{11}{|l|}{ Physical activity } \\
\hline None & 1458 & $(56.27)$ & 182.55 & $(1.21)$ & 126.51 & $(2.32)$ & 94.40 & $(1.11)$ & 123.51 & $(1.27)$ \\
\hline Moderate & 204 & $(7.87)$ & 184.92 & $(3.00)$ & 138.31 & $(7.15)$ & 93.85 & $(2.86)$ & 125.82 & (3.57) \\
\hline Hardly & 929 & $(35.85)$ & 182.08 & $(1.70)$ & 124.70 & $(3.00)$ & 94.58 & (1.48) & 123.31 & (1.65) \\
\hline$p$-value & & & \multicolumn{2}{|c|}{0.631} & \multicolumn{2}{|c|}{0.014} & \multicolumn{2}{|c|}{0.856} & \multicolumn{2}{|c|}{0.575} \\
\hline
\end{tabular}

$p$-values are calculated based on survey $t$-test for binominal groups (sex) and based on Wald F-test for categorical groups (age groups, BMI, household income, education levels, smoking status, drinking status, and physical activity); Abbreviations: SE, standard error; TC, total cholesterol; TG, triglyceride; LDL, low-density lipoprotein cholesterol; HDL-C, high density lipoprotein cholesterol; Non-HDL, non-high density lipoprotein cholesterol.

Table 2 shows the comparison of heavy metal concentrations in the non-dyslipidemia and the dyslipidemia group. Concentrations of $\mathrm{BPb}$ in the elevated lipid profile group of $\mathrm{TC}$, TG, LDL-C, and Non-HDL-C were significantly higher than that in the non-dyslipidemia group $(p<0.05)$. BHg concentrations were significantly higher in the dyslipidemia group of TC, TG, LDL-C, and Non-HDL-C than that in the non-dyslipidemia group $(p<0.05)$. $\mathrm{UHg}$ concentrations were significantly higher in the dyslipidemia group of LDL-C and Non-HDL-C than that in the non-dyslipidemia group $(p<0.05)$. The UCd concentrations were significantly higher in the dyslipidemia group of LDL-C and Non-HDL-C than that in the non-dyslipidemia group $(p<0.05)$.

Table 2. Geometric means of heavy metal concentrations, according to the dyslipidemia or nondyslipidemia group $(n=2591)$.

\begin{tabular}{|c|c|c|c|c|c|c|c|c|c|}
\hline \multirow{2}{*}{ TC $(\mathrm{mg} / \mathrm{dL})$} & \multirow[t]{2}{*}{$n$} & \multicolumn{2}{|c|}{$\begin{array}{c}\text { BPb } \\
(\mu \mathrm{g} / \mathrm{dL}(95 \% \mathrm{CIs}))\end{array}$} & \multicolumn{2}{|c|}{$\begin{array}{c}\text { BHg } \\
(\mu \mathrm{g} / \mathrm{L}(95 \% \mathrm{CIs}))^{\mathrm{a}}\end{array}$} & \multicolumn{2}{|c|}{$\begin{array}{c}\text { UHg } \\
(\mu \mathrm{g} / \mathrm{L}(95 \% \text { CIs }))^{a}\end{array}$} & \multicolumn{2}{|c|}{$\begin{array}{c}\text { UCd } \\
(\mu \mathrm{g} / \mathrm{L}(\mathbf{9 5} \% \mathrm{CIs}))\end{array}$} \\
\hline & & & & & & & & & \\
\hline$<200$ & 1703 & 1.50 & $(1.46,1.55)$ & 2.56 & $(2.41,2.71)$ & 0.38 & $(0.36,0.41)$ & 0.39 & $(0.36,0.42)$ \\
\hline$\geq 200$ & 888 & 1.64 & $(1.57,1.71) *$ & 3.06 & $(2.89,3.24) *$ & 0.42 & $(0.39,0.45)$ & 0.43 & $(0.39,0.47)$ \\
\hline \multicolumn{10}{|l|}{ TG (mg/dL) } \\
\hline$<150$ & 2254 & 1.45 & $(1.40,1.50)$ & 2.53 & $(2.38,2.68)$ & 0.39 & $(0.36,0.41)$ & 0.38 & $(0.35,0.42)$ \\
\hline$\geq 150$ & 337 & 1.72 & $(1.65,1.79) *$ & 3.02 & $(2.85,3.20)$ * & 0.40 & $(0.38,0.43)$ & 0.43 & $(0.39,0.47)$ \\
\hline \multicolumn{10}{|c|}{ LDL-C (mg/dL) } \\
\hline$<160$ & 2168 & 1.52 & $(1.47,1.56)$ & 2.62 & $(2.48,2.76)$ & 0.38 & $(0.36,0.40)$ & 0.39 & $(0.36,0.42)$ \\
\hline$\geq 160$ & 423 & 1.72 & $(1.63,1.83) *$ & 3.32 & $(3.10,3.56) *$ & 0.46 & $(0.41,0.51) *$ & 0.48 & $(0.43,0.53) *$ \\
\hline \multicolumn{10}{|c|}{ Non-HDL-C (mg/dL) } \\
\hline$<130$ & 2091 & 1.51 & $(1.46,1.55)$ & 2.61 & $(2.48,2.76)$ & 0.38 & $(0.36,0.40)$ & 0.39 & $(0.36,0.42)$ \\
\hline$\geq 130$ & 500 & 1.76 & $(1.67,1.86) *$ & 3.20 & $(2.97,3.45) *$ & 0.45 & $(0.41,0.50) *$ & 0.45 & $(0.40,0.50) *$ \\
\hline
\end{tabular}

${ }^{\text {a }}$ Total mercury, ${ }^{*} p$-value $<0.05$, Abbreviations: $\mathrm{CI}$, confidence interval; $\mathrm{BPb}$, blood lead; $\mathrm{BHg}$, blood mercury; $\mathrm{UHg}$, urinary mercury; UCd, urinary cadmium; TC, total cholesterol; Non-HDL, non-high density lipoprotein cholesterol; TG, triglyceride; LDL, low-density lipoprotein cholesterol.

Table 3 presents the adjusted ORs (95\% CIs) for dyslipidemia by heavy metals. $\mathrm{BPb}$ and $\mathrm{BHg}$ concentrations showed significant associations with a higher risk of dyslipidemia (all $p<0.05$ ). For $\mathrm{BPb}$, the ORs of the upper quartiles of elevated TC, LDL-C, and non-HDLC compared with the OR of the lowest quartile were 1.49 (95\% CI: 1.07-2.08; $p=0.084$ ), 1.57 (95\% CI: $1.02-2.40 ; p=0.041), 1.71$ (95\% CI: $1.09-2.68 ; p=0.049$ ), respectively. Compared with the OR in the lowest quartile of $\mathrm{BHg}$, the OR of elevated TC in the 4th quartile was 1.72 (95\% CI:1.21-2.44; $p=0.016$ ), and ORs for elevated LDL-C for the 2nd, 3rd, and 4th quartiles, compared with the OR of the 1st quartile, were 1.63 (95\% CI: 1.08-2.45), 1.77 
(95\% CI:1.17-2.68), and 2.21 (95\% CI:1.49-3.28), respectively ( $p$ for trend < 0.05). There are no significant associations between Uhg, UCd, and dyslipidemia. Additionally, we examined the association between heavy metals and serum lipid profiles for including $\mathrm{TG} \geq 400$. The results were similar to those obtained, with the exclusion of TG $\geq 400$ (Supplementary Materials, Table S1). After adjustment for heavy metal-related occupations or the high seafood dietary group, the results were consistent with those obtained with the non-adjustment models (Supplementary Materials, Tables S2 and S3).

Table 3. Multivariate logistic regression of serum lipid profiles by heavy metal concentrations in participants $(n=2591)$.

\begin{tabular}{|c|c|c|c|c|c|c|c|c|c|c|}
\hline \multicolumn{11}{|c|}{$\beta(95 \%$ CI $)$ of Serum Lipid Levels } \\
\hline & & $n$ & \multicolumn{2}{|c|}{$\begin{array}{c}\text { Elevated TC } \\
(\geq 200 \mathrm{mg} / \mathrm{dL})\end{array}$} & \multicolumn{2}{|c|}{$\begin{array}{c}\text { Elevated TG } \\
(\geq 150 \mathrm{mg} / \mathrm{dL})\end{array}$} & \multicolumn{2}{|c|}{$\begin{array}{l}\text { Elevated LDL-C } \\
(\geq 130 \mathrm{mg} / \mathrm{dL})\end{array}$} & \multicolumn{2}{|c|}{$\begin{array}{l}\text { Elevated Non-HDL-C } \\
\quad(\geq 160 \mathrm{mg} / \mathrm{dL})\end{array}$} \\
\hline Q1 & $(0.37-1.21)$ & 651 & & Reference & & Reference & & Reference & & Reference \\
\hline Q2 & $(1.21-1.65)$ & 644 & 1.05 & $(0.76,1.45)$ & 1.11 & $(0.77,1.62)$ & 0.96 & $(0.59,1.53)$ & 1.03 & $(0.66,1.60)$ \\
\hline Q3 & $(1.65-2.23)$ & 647 & 1.14 & $(0.87,1.50)$ & 1.13 & $(0.78,1.65)$ & 1.24 & $(0.84,1.84)$ & 1.27 & $(0.84,1.92)$ \\
\hline$\widehat{\mathrm{Q}} 4$ & $(2.23-20.58)$ & 649 & 1.49 & $(1.07,2.08)^{*}$ & 1.43 & $(0.98,2.08)$ & 1.57 & $(1.02,2.40)$ * & 1.71 & $(1.09,2.68)$ * \\
\hline & for trend & & & 0.084 & & 0.249 & & 0.041 & & 0.049 \\
\hline \multicolumn{11}{|c|}{$\mathrm{BHg}(\mu \mathrm{g} / \mathrm{L})^{\mathrm{a}}$} \\
\hline Q1 & $(0.33-1.85)$ & 647 & & Reference & & Reference & & Reference & & Reference \\
\hline Q2 & $(1.86-2.77)$ & 648 & 1.17 & $(0.86,1.59)$ & 1.23 & $(0.81,1.56)$ & 1.63 & $(1.08,2.45) *$ & 1.20 & $(0.80,1.79)$ \\
\hline Q3 & $(2.77-4.30)$ & 649 & 1.21 & $(0.87,1.68)$ & 1.00 & $(0.73,1.37)$ & 1.77 & $(1.17,2.68)$ * & 1.02 & $(0.64,1.64)$ \\
\hline Q4 & $(4.30-60.60)$ & 647 & 1.72 & $(1.21,2.44)^{*}$ & 0.86 & $(0.59,1.24)$ & 2.21 & $(1.49,3.28)^{*}$ & 1.52 & $(1.01,2.28)$ * \\
\hline & for trend & & & 0.016 & & 0.478 & & 0.012 & & 0.011 \\
\hline \multicolumn{11}{|c|}{$\mathrm{UHg}(\mu \mathrm{g} / \mathrm{L})^{a}$} \\
\hline Q1 & $(0.10-0.23)$ & 655 & & Reference & & Reference & & Reference & & Reference \\
\hline Q2 & $(0.24-0.35)$ & 641 & 0.87 & $(0.64,1.18)$ & 0.95 & $(0.66,1.36)$ & 0.89 & $(0.55,1.44)$ & 0.79 & $(0.51,1.20)$ \\
\hline Q3 & $(0.36-0.64)$ & 648 & 1.19 & $(0.85,1.66)$ & 1.10 & $(0.74,1.62)$ & 1.36 & $(0.88,2.11)$ & 1.32 & $(0.86,2.02)$ \\
\hline Q4 & $(0.65-8.70)$ & 647 & 1.32 & $(0.88,1.96)$ & 0.77 & $(0.52,1.15)$ & 1.55 & $(0.98,2.45)$ & 1.37 & $(0.89,2.10)$ \\
\hline & for trend & & & 0.154 & & 0.185 & & 0.055 & & 0.037 \\
\hline \multicolumn{11}{|c|}{$\mathrm{UCd}(\mu \mathrm{g} / \mathrm{L})$} \\
\hline Q1 & $(0.05-0.22)$ & 688 & & Reference & & Reference & & Reference & & Reference \\
\hline$\widehat{\mathrm{Q}} 2$ & $(0.22-0.45)$ & 607 & 1.00 & $(0.70,1.43)$ & 1.18 & $(0.88,1.58)$ & 0.84 & $(0.58,1.22)$ & 1.16 & $(0.65,2.06)$ \\
\hline Q3 & $(0.45-0.87)$ & 648 & 0.78 & $(0.56,1.09)$ & 1.06 & $(0.74,1.52)$ & 0.61 & $(0.39,0.94)$ & 1.72 & $(0.95,3.11)$ \\
\hline$\widehat{\mathrm{Q}} 4$ & $(0.87-16.82)$ & 648 & 0.86 & $(0.59,1.24)$ & 1.14 & $(0.83,1.56)$ & 0.85 & $(0.56,1.29)$ & 1.58 & $(0.83,2.99)$ \\
\hline \multicolumn{3}{|c|}{$p$ for trend } & \multicolumn{2}{|r|}{0.396} & \multicolumn{2}{|c|}{0.657} & \multicolumn{2}{|r|}{0.661} & \multicolumn{2}{|r|}{0.172} \\
\hline
\end{tabular}

${ }^{a}$ Total mercury, * $p$-value $<0.05$, Abbreviations: $\mathrm{CI}$, confidence interval; $\mathrm{BPb}$, blood lead; $\mathrm{BHg}$, blood mercury; $\mathrm{UHg}$, urinary mercury; UCd, urinary cadmium; TC, total cholesterol; Non-HDL, non-high density lipoprotein cholesterol; TG, triglyceride; LDL, low-density lipoprotein cholesterol.

Figure 2 presents the estimated associations between serum lipid profiles and heavy metal concentrations using multiple linear regression analysis. After multivariable adjustment, $\mathrm{BPb}, \mathrm{BHg}$, and $\mathrm{UHg}$ in the upper quartiles had higher TC, TG, LDL-C, and non-HDL-C levels than those in the lowest quartile. There is evidence of dose-response relationships between: $\mathrm{BPb}$ and TC, LDL-C, and non-HDL-C; BHg and TC and NonHDL-C; UHg and TC, LDL-C, and Non-HDL-C ( $p$ for trend $<0.05$ ). We did not observe dose-response relationships between the UCd concentrations and serum lipid profiles. 


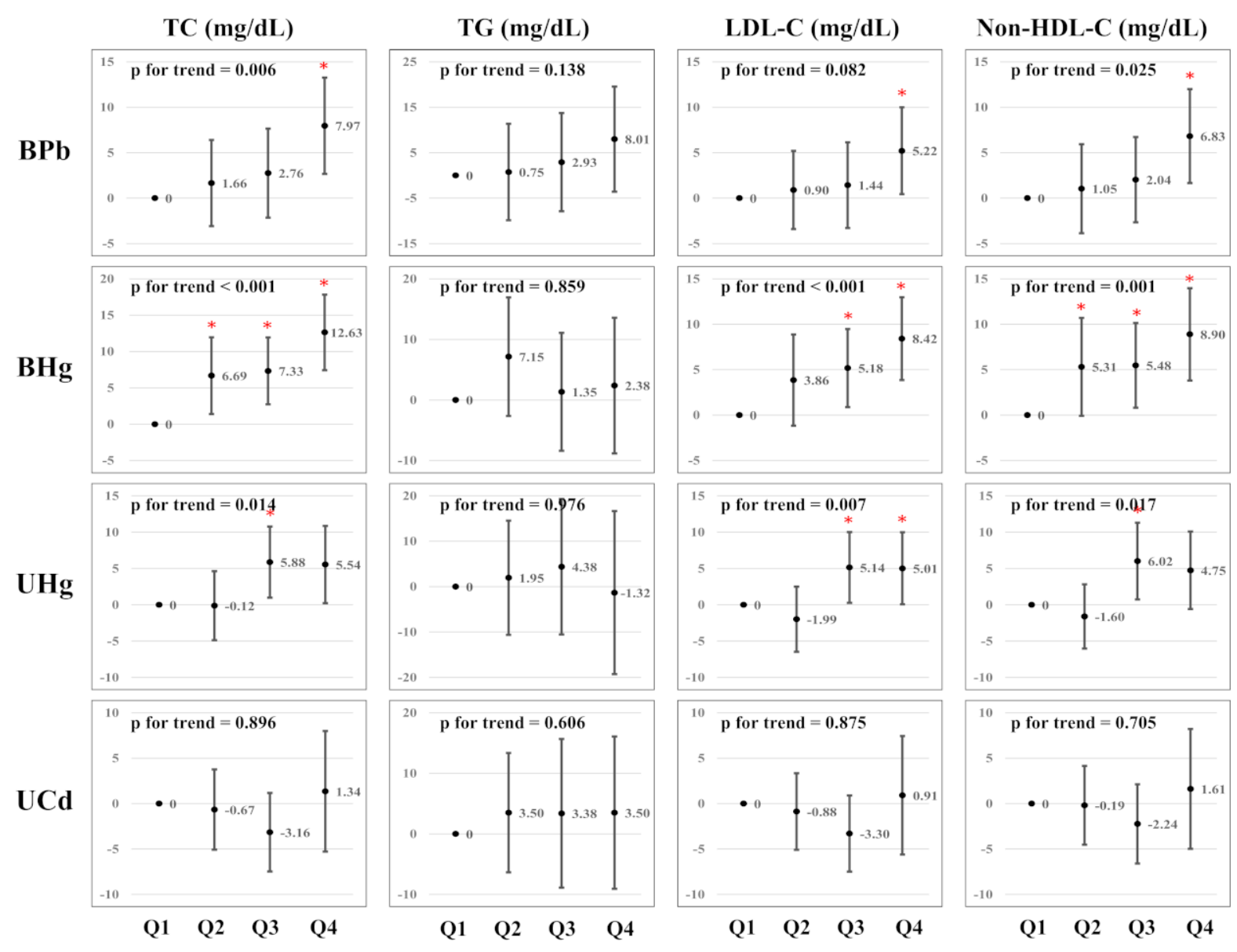

Figure 2. Multiple linear regression analysis of serum lipid profile by heavy metal concentrations $(n=2591)$. Asterisks $\left({ }^{*}\right)$ indicate significance level $(<0.05)$.

\section{Discussion}

In a representative sample of Korean adults, using KoNEHS 2015-2017, we examined the association between heavy metal exposure and serum lipid profiles. After adjusting for all covariates in multivariate regression analysis, it was observed that there was a positive association between high $\mathrm{BPb}, \mathrm{BHg}$, Uhg, and serum lipid profiles, including $\mathrm{TC}$, LDL-C, and non-HDL-C. In addition, high $\mathrm{BPb}$ and $\mathrm{BHg}$ were observed to be significantly associated with dyslipidemia in logistic regression analysis.

The Ministry of Environment has been involved in ongoing efforts to reduce environmental exposure to heavy metals since 1988 [45]. According to data from the KoNEHS (2009-2017), the concentration of heavy metals in Korean adults is decreasing, but it is still higher than that found in the adults of developed countries [33]. The Korean geography (island/coastal country) may influence high heavy metal concentrations, owing to the culture of high seafood consumption [39]. Seafood consumption has been reported as one of the main sources of heavy metal exposure in the general population [46]. In addition, soil and groundwater contamination, caused by abandoned mines in Korea, is a serious social problem [47]. The traditional Asian food culture, which frequently consumes grains and herbal medicines grown in contaminated soil, is supported by the high concentration of heavy metals in Korea [48].

Previous epidemiological studies have suggested an association between dyslipidemia and heavy metal exposure. According to a study using the National Health and Nutrition Examination Survey (NHANES), the ORs for TC, non-HDL-C, and LDL-C were 1.88, 1.59, and 1.68 times higher in the highest $\mathrm{BPb}$ quartile $(>1.90 \mu \mathrm{g} / \mathrm{dL})$ than that in the lowest quartile $(\leq 0.76 \mu \mathrm{g} / \mathrm{dL})$, respectively [29]. Another study found that TC and LDL-C levels 
were 1.5-2.0 and 1.6-2.4 times higher $(p<0.001)$ in the occupational $\mathrm{Pb}$ exposure group $(27.00-48.90 \mu \mathrm{g} / \mathrm{dL}$ for $\mathrm{BPb})$ than in the control group $(15.78 \mu \mathrm{g} / \mathrm{dL}$ for $\mathrm{BPb})$, whereas TG and HDL-C levels did not show a significant association $(p<0.05)$ [49]. Furthermore, a study using the KoNEHS observed that BHg concentrations are significantly higher in the hyperlipidemia group (4.03 and $2.83 \mu \mathrm{g} / \mathrm{L}$ for male and female) than that in the non-hyperlipidemia group (3.48 and $2.69 \mu \mathrm{g} / \mathrm{L}$ of male and female), and individuals with higher $\mathrm{BHg}$ concentrations have a $11 \%$ higher risk of hyperlipidemia [50]. Significant increases in TC, HDL-C, and LDL-C levels are reported with increasing BHg concentrations in Korean adults, based on the KoNEHS [40,51].

The toxic mechanism of lipid metabolism by heavy metal exposure is not yet completely understood, but it is generally associated with oxidative stress. Oxidative stress is caused by an imbalance between the antioxidant defense system and the free radical production system [24]. Heavy metal binds to sulfhydryl protein groups and depletes glutathione, leading to oxidative stress through reactive oxygen species (ROS) generation [52]. Oxidative stress activates several protein phosphorylation pathways, including phosphatidylinositol 3-kinase (PI3K) and MAPK, c-Jun N terminal kinase (JNK), and stressactivated protein kinase (SAPK) [53]. This activity is involved in the apoptotic process of pancreatic $\beta$-cells responsible for insulin production, which plays a major role in glycemic homeostasis, leading to insulin resistance $[20,54]$. This condition can lead to endothelial dysfunction through decreased vasodilator production and increased vasoconstrictor production [55]. Animal studies have demonstrated that heavy metal exposure impairs glucose metabolism by pancreatic $\beta$-cell damage. In vitro and in vivo studies have proved that chronic exposure to $\mathrm{Pb}$ affects the pancreas and disrupts glucose homeostasis [56,57]. Exposure to $\mathrm{Hg}$ induces ROS production, impaired insulin secretion, and apoptosis of $\beta$-cell-derived HIT-T15 cells [58,59].

In our study, UCd concentrations were not significantly associated with elevated serum lipid levels. According to a previous study, a positive correlation was observed between $\mathrm{BCd}$ concentrations and HDL-C risk in Korean adults [30]. In addition, an increased prevalence of high TC, TG, and LDL-C, as well as low HDL-C, with increasing BCd concentrations was observed in Chinese occupationally exposed to $C d$ [60]. In contrast, several studies using NHANES data have shown no significant association between UCd or BCd levels and metabolic syndrome risk [61,62], which is consistent with our study findings. These conflicting results might be due to differences in individual participant characteristics, exposure levels, sampling bias, size, and covariate settings [29]. Some, kinds of biosamples (i.e., urine or blood) might affect the associations because UCd serves as a biomarker of long-term cadmium exposure, and BCd serves as a biomarker of recent cadmium exposure, $[63,64]$.

Our study has several limitations that warrant discussion. First, it is a cross-sectional observational study based on a single measurement. Thus, it cannot indicate the exact causal relationship of the observed association. Second, since heavy metals in blood reflect relatively recent exposure, there is a limit to explaining the burden on the body due to long-term exposure. Third, although this study focused on $\mathrm{Pb}, \mathrm{Cd}$, and $\mathrm{Hg}$ exposure, these may be accompanied by potential exposure to other metals.

However, our study has several notable advantages. First, we used individual blood or urine heavy metal concentrations to account for heavy metal exposure levels, and we observed the association with serum lipid profiles. Second, we used three types $(\mathrm{Pb}$, $\mathrm{Cd}$, and $\mathrm{Hg}$ ) of heavy metal biomarkers to provide the opportunity to observe different associations between each heavy metal exposure and serum lipid profiles. Third, our results can be interpreted as the results of the national population because we used data from KoNEHS, a large representative sample of Korean adults. The results of our study provide epidemiological evidence for an association with dyslipidemia and current heavy metal exposure levels in Koreans. 


\section{Conclusions}

We assessed the association between heavy metal exposure and dyslipidemia using data from a nationally representative adult population in Korea. Our findings showed a positive association between $\mathrm{BPb}, \mathrm{BHg}$, and $\mathrm{UHg}$ concentrations and serum lipid profiles. In addition, $\mathrm{BPb}$ and $\mathrm{BHg}$ concentrations were positively associated with a prevalence of dyslipidemia. These results support evidence that heavy metal exposure may be an important risk factor for abnormal lipid metabolism. Results from this study, in conjunction with others, strengthen the concern on heavy metal effects at low-level when evaluating heavy metal regulations concerning adverse health effects. However, further studies are needed to elucidate the mechanisms supporting the association between heavy metal exposure and dyslipidemia in the general population.

Supplementary Materials: The following supporting information can be downloaded at: https: / / www.mdpi.com/article/10.3390/ijerph19063181/s1, Table S1: Multivariate logistic regression of serum lipid profiles by heavy metal concentrations including TG $\geq 400$ in participants $(n=2742)$; Table S2: High seafood dietary group-adjusted OR (95\% CIs) of serum lipid profiles by heavy metal concentrations in participants $(n=2591)$; Table S3: Heavy metals related occupation-adjusted OR ( $95 \%$ CIs) of serum lipid profiles by heavy metal concentrations in participants $(n=2591)$.

Author Contributions: Conceptualization, D.-w.K. and J.O.; methodology, D.-w.K. and J.O.; software, D.-w.K. and J.O.; formal analysis, D.-w.K. and J.O.; writing-original draft preparation, D.-w.K. and J.O.; writing-review and editing, D.-w.K., J.O., K.-W.M. and C.-H.P. All authors have read and agreed to the published version of the manuscript.

Funding: This survey was supported by a grant from the National Institute of Environmental Research funded by the Ministry of Environment (MOE) of Korea (NIER-2017-01-01-001).

Institutional Review Board Statement: Ethical review and approval were waived for this study, due to existing information, data, documents, and records.

Informed Consent Statement: Not applicable.

Data Availability Statement: This study used data from the Second Korean National Environmental Health Survey (KoNEHS) which was conducted by the Ministry of Environment, National Institute of Environmental Research. The data presented in this study are available on request from the corresponding authors. The data are not publicly available due to protect personal information.

Conflicts of Interest: The authors declare no conflict of interest.

\section{References}

1. Pitsavos, C.; Panagiotakos, D.; Weinem, M.; Stefanadis, C. Diet, exercise and the metabolic syndrome. Rev. Diabet. Stud. 2006, 3, 118. [CrossRef] [PubMed]

2. Tóth, P.P.; Potter, D.; Ming, E.E. Prevalence of lipid abnormalities in the united states: The national health and nutrition examination survey 2003-2006. J. Clin. Lipidol. 2012, 6, 325-330. [CrossRef] [PubMed]

3. Srikanth, S.; Deedwania, P. Management of dyslipidemia in patients with hypertension, diabetes, and metabolic syndrome. Curr. Hypertens. Rep. 2016, 18, 1-10. [CrossRef]

4. Pires, A.; Sena, C.; Seiça, R. Dyslipidemia and cardiovascular changes in children. Curr. Opin. Cardiol. 2016, 31, 95-100. [CrossRef] [PubMed]

5. Koba, S.; Hirano, T. Dyslipidemia and atherosclerosis. Nihon Rinsho. Jpn. J. Clin. Med. 2011, 69, $138-143$.

6. Asghari, S.; Aref-Eshghi, E.; Godwin, M.; Duke, P.; Williamson, T.; Mahdavian, M. Single and mixed dyslipidaemia in Canadian primary care settings: Findings from the Canadian primary care sentinel surveillance network database. BMJ Open 2015, 5, e007954. [CrossRef]

7. Jang, S.; Lee, J. Prevalence and management of dyslipidemia among Korean adults: KNHANES 2010-2012. J. Korea Acad.-Ind. Coop. Soc. 2015, 16, 7978-7989.

8. Jeon, M.Y.; Choi, W.H.; Seo, Y.M. Risk factors of dyslipidemia and related factors of medication adherence in Korea adults: KNHANES 2013-2015. J. Korean Biol. Nurs. Sci. 2017, 19, 131-140.

9. Knopp, R.H.; LaRosa, J.C.; Burkman, R.T., Jr. Contraception and dyslipidemia. Am. J. Obstet. Gynecol. 1993, 168, 1994-2005. [CrossRef]

10. Carmena, R. Type 2 diabetes, dyslipidemia, and vascular risk: Rationale and evidence for correcting the lipid imbalance. Am. Heart J. 2005, 150, 859-870. [CrossRef] 
11. Packard, C.J.; Boren, J.; Taskinen, M.-R. Causes and consequences of hypertriglyceridemia. Front. Endocrinol. 2020, 11, 252. [CrossRef] [PubMed]

12. National Cholesterol Education Program (NCEP). Third Report of the National Cholesterol Education Program (NCEP) Expert Panel on Detection, Evaluation, and Treatment of High Blood Cholesterol In Adults (Adult Treatment Panel III)-The Program. Circulation 2002, 106, 3143-3421. [CrossRef]

13. Jacobson, T.A.; Ito, M.K.; Maki, K.C.; Orringer, C.E.; Bays, H.E.; Jones, P.H.; McKenney, J.M.; Grundy, S.M.; Gill, E.A.; Wild, R.A. National Lipid Association recommendations for patient-centered management of dyslipidemia: Part 1-Executive summary. J. Clin. Lipidol. 2014, 8, 473-488. [CrossRef] [PubMed]

14. Hedayatnia, M.; Asadi, Z.; Zare-Feyzabadi, R.; Yaghooti-Khorasani, M.; Ghazizadeh, H.; Ghaffarian-Zirak, R.; Nosrati-Tirkani, A.; Mohammadi-Bajgiran, M.; Rohban, M.; Sadabadi, F. Dyslipidemia and cardiovascular disease risk among the MASHAD study population. Lipids Health Dis. 2020, 19, 1-11. [CrossRef]

15. Mozaffarian, D.; Benjamin, E.J.; Go, A.S.; Arnett, D.K.; Blaha, M.J.; Cushman, M.; Das, S.R.; De Ferranti, S.; Després, J.-P.; Fullerton, H.J. Heart disease and stroke statistics-2016 update: A report from the American Heart Association. Circulation 2016, 133, e38-e360. [CrossRef]

16. Feng, H.; Ha, F.; Hu, G.; Wu, Y.; Yu, S.; Ji, Z.; Feng, W.; Wang, T.; Jia, G. Concentration of chromium in whole blood and erythrocytes showed different relationships with serum apolipoprotein levels in Cr (VI) exposed subjects. J. Trace Elem. Med. Biol. 2018, 50, 384-392. [CrossRef]

17. Mendrick, D.L.; Diehl, A.M.; Topor, L.S.; Dietert, R.R.; Will, Y.; La Merrill, M.A.; Bouret, S.; Varma, V.; Hastings, K.L.; Schug, T.T. Metabolic syndrome and associated diseases: From the bench to the clinic. Toxicol. Sci. 2018, 162, 36-42. [CrossRef]

18. Zhao, L.; Zhu, Y.; Chen, Z.; Xu, H.; Zhou, J.; Tang, S.; Xu, Z.; Kong, F.; Li, X.; Zhang, Y. Cardiopulmonary effects induced by occupational exposure to titanium dioxide nanoparticles. Nanotoxicology 2018, 12, 169-184. [CrossRef]

19. Cho, H.W.; Kim, S.-H.; Park, M.J. An association of blood mercury levels and hypercholesterolemia among Korean adolescents. Sci. Total Environ. 2020, 709, 135965. [CrossRef]

20. Chen, Y.; Wang, J.; Gao, W.; Sun, X.; Xu, S. Comprehensive analysis of heavy metals in soils from Baoshan District, Shanghai: A heavily industrialized area in China. Environ. Earth Sci. 2012, 67, 2331-2343. [CrossRef]

21. Mahurpawar, M. Effects of heavy metals on human health. Int. J. Res.-Granthaalayah 2015, 3, 1-7. [CrossRef]

22. Zhang, Y.; Tian, Y.; Shen, M.; Zeng, G. Heavy metals in soils and sediments from Dongting Lake in China: Occurrence, sources, and spatial distribution by multivariate statistical analysis. Environ. Sci. Pollut. Res. 2018, 25, 13687-13696. [CrossRef] [PubMed]

23. Kaur, R.; Sharma, S.; Kaur, H. Heavy metals toxicity and the environment. J. Pharmacogn. Phytochem. SP1 2019, 247-249. [CrossRef]

24. Fatema, K.; Shoily, S.S.; Ahsan, T.; Haidar, Z.; Sumit, A.F.; Sajib, A.A. Effects of arsenic and heavy metals on metabolic pathways in cells of human origin: Similarities and differences. Toxicol. Rep. 2021, 8, 1109-1120. [CrossRef] [PubMed]

25. Fu, Z.; Xi, S. The effects of heavy metals on human metabolism. Toxicol. Mech. Methods 2020, 30, 167-176. [CrossRef] [PubMed]

26. Ercal, N.; Gurer-Orhan, H.; Aykin-Burns, N. Toxic metals and oxidative stress part I: Mechanisms involved in metal-induced oxidative damage. Curr. Top. Med. Chem. 2001, 1, 529-539. [CrossRef]

27. Navas-Acien, A.; Guallar, E.; Silbergeld, E.K.; Rothenberg, S.J. Lead exposure and cardiovascular disease-A systematic review. Environ. Health Perspect. 2007, 115, 472-482. [CrossRef]

28. Poręba, R.; Gać, P.; Poręba, M.; Andrzejak, R. Environmental and occupational exposure to lead as a potential risk factor for cardiovascular disease. Environ. Toxicol. Pharmacol. 2011, 31, 267-277. [CrossRef]

29. Xu, H.; Mao, Y.; Xu, B.; Hu, Y. Low-level environmental lead and cadmium exposures and dyslipidemia in adults: Findings from the NHANES 2005-2016. J. Trace Elem. Med. Biol. 2021, 63, 126651. [CrossRef]

30. Kim, K. Blood cadmium concentration and lipid profile in Korean adults. Environ. Res. 2012, 112, 225-229. [CrossRef]

31. Park, K.; Seo, E. Toenail mercury and dyslipidemia: Interaction with selenium. J. Trace Elem. Med. Biol. 2017, 39, 43-49. [CrossRef] [PubMed]

32. Tchounwou, P.B.; Yedjou, C.G.; Patlolla, A.K.; Sutton, D.J. Heavy metal toxicity and the environment. Mol. Clin. Environ. Toxicol. 2012, 101, 133-164.

33. Kim, D.-W.; Ock, J.; Moon, K.-W.; Park, C.-H. Association between Pb, Cd, and Hg exposure and liver injury among Korean adults. Int. J. Environ. Res. Public Health 2021, 18, 6783. [CrossRef] [PubMed]

34. NIER. Guidebook of the National Institute of Environmental Research; NIER: Incheon, Korea, 2019.

35. NIER. Analysis Manual of the National Institute of Environmental Research (Heavy Metals); NIER: Incheon, Korea, 2018.

36. NIER. Clinical Analysis Manual of the National Institute of Environmental Research; NIER: Incheon, Korea, 2019.

37. Ma, C.; Schupp, C.; Armstrong, E.; Armstrong, A. Psoriasis and dyslipidemia: A population-based study analyzing the National Health and Nutrition Examination Survey (NHANES). J. Eur. Acad. Dermatol. Venereol. 2014, 28, 1109-1112. [CrossRef]

38. Friedewald, W.T.; Levy, R.I.; Fredrickson, D.S. Estimation of the concentration of low-density lipoprotein cholesterol in plasma, without use of the preparative ultracentrifuge. Clin. Chem. 1972, 18, 499-502. [CrossRef]

39. Choi, H.; Shim, J.-S.; Lee, M.H.; Yoon, Y.M.; Choi, D.P.; Kim, H.C. Comparison of formulas for calculating low-density lipoprotein cholesterol in general population and high-risk patients with cardiovascular disease. Korean Circ. J. 2016, 46, 688-698. [CrossRef]

40. Sohn, S.H.; Heo, H.C.; Jo, S.; Park, C.; Sakong, J. The association between mercury concentrations and lipid profiles in the Korean National Environmental Health Survey (KoNEHS) cycle 3. Ann. Occup. Environ. Med. 2020, 32, e19. [CrossRef]

41. Virani, S.S. Non-HDL cholesterol as a metric of good quality of care: Opportunities and challenges. Tex. Heart Inst. J. 2011, 38, 160. 
42. Havel, R.J.; Rapaport, E. Management of primary hyperlipidemia. N. Engl. J. Med. 1995, 332, 1491-1498. [CrossRef]

43. Rana, J.S.; Boekholdt, S.M.; Kastelein, J.J.; Shah, P.K. The role of non-HDL cholesterol in risk stratification for coronary artery disease. Curr. Atheroscler. Rep. 2012, 14, 130-134. [CrossRef]

44. Ni, W.-Q.; Liu, X.-L.; Zhuo, Z.-P.; Yuan, X.-L.; Song, J.-P.; Chi, H.-S.; Xu, J. Serum lipids and associated factors of dyslipidemia in the adult population in Shenzhen. Lipids Health Dis. 2015, 14, 1-11. [CrossRef] [PubMed]

45. Oh, S.-E.; Kim, G.B.; Hwang, S.H.; Ha, M.; Lee, K.-M. Longitudinal trends of blood lead levels before and after leaded gasoline regulation in Korea. Environ. Health Toxicol. 2017, 32, e2017019. [CrossRef] [PubMed]

46. Castro-González, M.; Méndez-Armenta, M. Heavy metals: Implications associated to fish consumption. Environ. Toxicol. Pharmacol. 2008, 26, 263-271. [CrossRef] [PubMed]

47. Ok, Y.S.; Usman, A.R.; Lee, S.S.; Abd El-Azeem, S.A.; Choi, B.; Hashimoto, Y.; Yang, J.E. Effects of rapeseed residue on lead and cadmium availability and uptake by rice plants in heavy metal contaminated paddy soil. Chemosphere 2011, 85, 677-682 [CrossRef]

48. Park, S.; Lee, B.-K. Strong positive association of traditional Asian-style diets with blood cadmium and lead levels in the Korean adult population. Int. J. Environ. Health Res. 2013, 23, 531-543. [CrossRef]

49. Ademuyiwa, O.; Ugbaja, R.N.; Idumebor, F.; Adebawo, O. Plasma lipid profiles and risk of cardiovascular disease in occupational lead exposure in Abeokuta, Nigeria. Lipids Health Dis. 2005, 4, 1-7. [CrossRef]

50. Lee, S.; Cho, S.-R.; Jeong, I.; Park, J.B.; Shin, M.-Y.; Kim, S.; Kim, J.H. Mercury exposure and associations with hyperlipidemia and elevated liver enzymes: A nationwide cross-sectional survey. Toxics 2020, 8, 47. [CrossRef]

51. Cho, Y.M. Fish consumption, mercury exposure, and the risk of cholesterol profiles: Findings from the Korea National Health and Nutrition Examination Survey 2010-2011. Environ. Health Toxicol. 2017, 32, e2017014. [CrossRef]

52. Liu, J.; Qu, W.; Kadiiska, M.B. Role of oxidative stress in cadmium toxicity and carcinogenesis. Toxicol. Appl. Pharmacol. 2009, 238, 209-214. [CrossRef]

53. Matsuoka, M.; Igisu, H. Effects of heavy metals on mitogen-activated protein kinase pathways. Environ. Health Prev. Med. 2002, 6 , 210-217. [CrossRef]

54. Newsholme, P.; Keane, K.N.; Carlessi, R.; Cruzat, V. Oxidative stress pathways in pancreatic $\beta$-cells and insulin-sensitive cells and tissues: Importance to cell metabolism, function, and dysfunction. Am. J. Physiol.-Cell Physiol. 2019, 317, C420-C433. [CrossRef] [PubMed]

55. Rask-Madsen, C.; King, G.L. Mechanisms of disease: Endothelial dysfunction in insulin resistance and diabetes. Nat. Clin. Pract. Endocrinol. Metab. 2007, 3, 46-56. [CrossRef] [PubMed]

56. Mostafalou, S.; Baeeri, M.; Bahadar, H.; Soltany-Rezaee-Rad, M.; Gholami, M.; Abdollahi, M. Molecular mechanisms involved in lead induced disruption of hepatic and pancreatic glucose metabolism. Environ. Toxicol. Pharmacol. 2015, 39, 16-26. [CrossRef] [PubMed]

57. Tyrrell, J.B.; Hafida, S.; Stemmer, P.; Adhami, A.; Leff, T. Lead (Pb) exposure promotes diabetes in obese rodents. J. Trace Elem. Med. Biol. 2017, 39, 221-226. [CrossRef]

58. Chen, Y.W.; Huang, C.F.; Yang, C.Y.; Yen, C.C.; Tsai, K.S.; Liu, S.H. Inorganic mercury causes pancreatic $\beta$-cell death via the oxidative stress-induced apoptotic and necrotic pathways. Toxicol. Appl. Pharmacol. 2010, 243, 323-331. [CrossRef]

59. Schumacher, L.; Abbott, L.C. Effects of methyl mercury exposure on pancreatic beta cell development and function. J. Appl. Toxicol. 2017, 37, 4-12. [CrossRef]

60. Zhou, Z.; Lu, Y.-h.; Pi, H.-f.; Gao, P.; Li, M.; Zhang, L.; Pei, L.-p.; Mei, X.; Liu, L.; Zhao, Q. Cadmium exposure is associated with the prevalence of dyslipidemia. Cell. Physiol. Biochem. 2016, 40, 633-643. [CrossRef]

61. Lee, B.-K.; Kim, Y. Association of blood cadmium level with metabolic syndrome after adjustment for confounding by serum ferritin and other factors: 2008-2012 Korean National Health and Nutrition Examination Survey. Biol. Trace Elem. Res. 2016, 171, 6-16. [CrossRef]

62. Noor, N.; Zong, G.; Seely, E.W.; Weisskopf, M.; James-Todd, T. Urinary cadmium concentrations and metabolic syndrome in US adults: The National Health and Nutrition Examination Survey 2001-2014. Environ. Int. 2018, 121, 349-356. [CrossRef]

63. Järup, L.; Åkesson, A. Current status of cadmium as an environmental health problem. Toxicol. Appl. Pharmacol. 2009, 238, 201-208. [CrossRef]

64. Lin, J.; Zhang, F.; Lei, Y. Dietary intake and urinary level of cadmium and breast cancer risk: A meta-analysis. Cancer Epidemiol. 2016, 42, 101-107. [CrossRef] [PubMed] 